\title{
Using glycerin with chitosan extracted from shrimp residue to enhance rumen fermentation and feed use in native Thai bulls
}

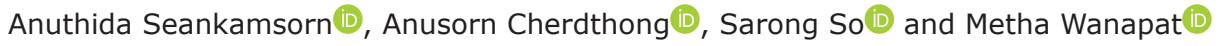 \\ Department of Animal Science, Tropical Feed Resources Research and Development Center, Faculty of Agriculture, Khon \\ Kaen University, Khon Kaen 40002, Thailand. \\ Corresponding author: Anusorn Cherdthong, e-mail: anusornc@kku.ac.th \\ Co-authors: AS: aontoranu@gmail.com, SS: sarong07so@gmail.com, MW: metha@kku.ac.th \\ Received: 09-11-2020, Accepted: 05-04-2021, Published online: 12-05-2021
}

doi: www.doi.org/10.14202/vetworld.2021.1158-1164 How to cite this article: Seankamsorn A, Cherdthong A, So S, Wanapat M (2021) Using glycerin with chitosan extracted from shrimp residue to enhance rumen fermentation and feed use in native Thai bulls, Veterinary World, 14(5): 1158-1164.

\begin{abstract}
Background and Aim: Crude glycerin is changed to propionate in the rumen, while chitosan can be used as a feed supplement to increase propionic acid concentration and decrease methane $\left(\mathrm{CH}_{4}\right)$ production. We hypothesized that supplementation with a combination of a high level of crude glycerin with chitosan could have a beneficial effect on ruminal fermentation and mitigate $\mathrm{CH}_{4}$ production. This study aimed to explore the combined effects of crude glycerin and chitosan supplementation on nutrient digestibility, rumen fermentation, and $\mathrm{CH}_{4}$ calculation in native Thai bulls.

Materials and Methods: Four 2-year-old native Thai bulls, weighing $150 \pm 20 \mathrm{~kg}$, were kept in a $2 \times 2$ factorial arrangement in a $4 \times 4$ Latin square design. Factor A represented the incorporation of crude glycerin at $10.5 \%$ and $21 \%$ of the dry matter (DM) of a total mixed ration (TMR), and factor B represented the supplementation of chitosan at $1 \%$ and $2 \%$ DM of a TMR.

Results: Increasing levels of crude glycerin at $21 \%$ decreased DM intake by $0.62 \mathrm{~kg} / \mathrm{day}$ compared with $10.5 \%$ crude glycerin $(p<0.05)$, whereas nutrient digestibility did not change $(p>0.05)$. The incorporated crude glycerin and supplemented chitosan levels did not affect the $\mathrm{pH}$, temperature, concentrations of ammonia-nitrogen, microbial population, and blood urea nitrogen $(p>0.05)$. Supplemented chitosan and incorporated crude glycerin did not show any interaction effects on the molar portions and total volatile fatty acids (VFAs), except estimated $\mathrm{CH}_{4}$. Increasing the incorporated crude glycerin levels increased propionate and decreased the ratio of acetate to propionate ratio, whereas levels of butyrate, acetate, and total VFAs were unchanged. The combination of crude glycerin at $21 \%$ in the TMR with chitosan at $2 \%$ reduced $\mathrm{CH}_{4}$ estimation by $5.08 \%$ compared with the other feed treatment.
\end{abstract}

Conclusion: Increasing incorporated crude glycerin levels in a TMR significantly elevated the propionate concentration, whereas combining $21 \%$ crude glycerin in the TMR diet with $2 \%$ chitosan supplementation could depress $\mathrm{CH}_{4}$ estimation more effectively than adding one of these supplements alone.

Keywords: crude glycerin, digestibility, incorporation, intake, volatile fatty acids.

\section{Introduction}

Crude glycerin, which is a biodiesel by-product, has been used as an energy source for animals in supplements and incorporated with other energy-rich ingredients in feed rations [1]. Crude glycerin has been used as a feedstuff for animals, primarily to reduce production costs due to the rising costs of corn and concentrate [2]. Crude glycerin is changed to propionate in the rumen, where it acts as a substrate for glucose production [3]. In addition, crude glycerin can stimulate a shift in carbohydrate fermentation through the synthesis of propionate from acetate. This shift affects the overall electron balance in the rumen and decreases the availability of hydrogen for methane $\left(\mathrm{CH}_{4}\right)$ production [4]. In agreement with these results,

Copyright: Seankamsorn, et al. Open Access. This article is distributed under the terms of the Creative Commons Attribution 4.0 International License (http://creativecommons.org/licenses/ by/4.0/), which permits unrestricted use, distribution, and reproduction in any medium, provided you give appropriate credit to the original author(s) and the source, provide a link to the Creative Commons license, and indicate if changes were made. The Creative Commons Public Domain Dedication waiver (http:// creativecommons.org/publicdomain/zero/1.0/) applies to the data made available in this article, unless otherwise stated.
Chanjula et al. [5] demonstrated that the inclusion of up to $20 \%$ crude glycerin in goat diets increased ruminal propionate concentration and reduced $\mathrm{CH}_{4}$ formation. In contrast, Karlsson et al. [3] found that glycerin inclusion $\left(20 \%\right.$ dry matter [DM]) increased $\mathrm{CH}_{4}$ production compared with a diet containing wheat starch. These differences in increasing and decreasing $\mathrm{CH}_{4}$ emissions could be because of the different variables that influence $\mathrm{CH}_{4}$ emission measurements, including the dose test, quality of glycerin, experimental animals, and diets fed to the animals. Thus, the utilization of glycerin is still required to determine the influence of specific components on rumen fermentation and $\mathrm{CH}_{4}$ emissions.

Biopolymer chitosan can be extracted from shrimp shell waste [6], and chitosan can be used as a feed supplement to improve digestibility, increase propionic acid concentration, and decrease $\mathrm{CH}_{4}$ production [6-8]. Haryati et al. [7] revealed that chitosan might have a mechanical influence similar to monensin, which is associated with shifts in volatile fatty acid (VFA) profiles, primarily reducing acetate and improving propionate, as well as depressing $\mathrm{CH}_{4}$ 
emissions. Furthermore, Zanferari et al. [8] explained that chitosan might inhibit the permeability of methanogenic bacteria cell walls and the direct interruption of methanogenic growth.

We hypothesized that supplementation with a combination of a high level of crude glycerin with chitosan could have a beneficial effect on ruminal fermentation and mitigate $\mathrm{CH}_{4}$ production. In a previous in vitro study, a combination of crude glycerin incorporated into a total mixed ration (TMR) at $21 \%$ and supplemented with $2 \%$ chitosan was shown to increase propionate concentrations and decreased $\mathrm{CH}_{4}$ [8]. However, an in vivo study on the combined effect of crude glycerin and chitosan has not yet been conducted.

Therefore, this study aimed to explore the combined effects of crude glycerin and chitosan supplementation on nutrient digestibility, ruminal fermentation, and $\mathrm{CH}_{4}$ emissions in Thai native bulls.

\section{Materials and Methods}

\section{Ethical approval}

The approval no. AEKKU 9/2561 was issued by the committees of the Animal Ethics of Khon Kaen University to ensure the welfare of the animal.

\section{Study period and location}

This study was conducted from July 2019 to October 2019 at Tropical Feed Resources Research and Development Center, Faculty of Agriculture, Khon Kaen University.

\section{Dietary preparation}

Chitosan was prepared following Toan [9]. Fresh shrimp shells were obtained from a local market in Khon Kaen Province, Thailand, and washed with clean water. Autolysis of the shrimp shells was conducted by adding $0.68 \mathrm{M} \mathrm{HCl}$ solution $(1: 5 \mathrm{w} / \mathrm{v})$ at $26-30^{\circ} \mathrm{C}$ for 2 days. The sediment was washed and soaked in tap water for 6-8 h. Then, it was removed from the water, and protein was eliminated using $\mathrm{NaOH}$ solution $(0.62 \mathrm{M} ; 1: 5 \mathrm{w} / \mathrm{v})$ at $26-30^{\circ} \mathrm{C}$ for $20 \mathrm{~h}$. Acetyl groups were removed from the chitin yield using $\mathrm{NaOH}$ at $65^{\circ} \mathrm{C}$ for $20 \mathrm{~h}$, after which chitosan was obtained. The chitosan was washed and sundried for 1-2 days before being tested. The chemical composition of the chitosan is provided in Table-1 [10]. Biodiesel production by the Used Oil Project, Khon Kaen University, Thailand, was used to obtain crude glycerin, and its chemical composition is provided in Table-1.

Cattle, experimental design, and feeding management

Four 2-year-old Thai native bulls, weighing $150 \pm 20 \mathrm{~kg}$, were kept in a $2 \times 2$ factorial arrangement in a $4 \times 4$ Latin square design. Factor A represented the incorporation of crude glycerin at $10.5 \%$ and $21 \%$ of the DM of a TMR, and factor B represented the supplementation of chitosan at $1 \%$ and $2 \%$ DM of a TMR. The ingredients and chemical composition of the TMR incorporated with crude glycerin are provided in Table-2. All diets were fed ad libitum daily to bulls at 07:00 and 16:00. An individual pen was prepared for each bull and was equipped with accessible water and a mineral block. The study involved four periods, and each period lasted 21 days. The first 14 days in each period were used for adapting the bulls to the TMR, and the last 7 days were used for data collection. During the past 7 days, the bulls were placed in a metabolism crate and continuously fed their respective diets. The intake of the TMR and refusal was recorded daily.

\section{Sample collection and analysis}

The TMR and refusal diets were sampled daily with duplication during the past 7 days of every period. Fecal samples were collected during the past 7 days of each period using a total collection protocol, as the cattle were on metabolism crates to determine the digestibility of the nutrients. About $5 \%$ of total fresh weight of fecal matter was sampled and separated into two parts, and the first part was used for DM determination every day. The last part was stored in a refrigerator and mixed for each animal at the end of each period for chemical measurement. The TMR, refusal, and fecal samples were separated into two parts: The first part was prepared to evaluate the initial DM and the second part was pooled for each bull, kept at $-10^{\circ} \mathrm{C}$, and then subsequently analyzed. The pooled TMR, refusal, and fecal matter were thawed, oven-dried at a temperature of $60^{\circ} \mathrm{C}$, milled through a $1 \mathrm{~mm}$ screen, and used to analyze DM, crude protein (CP), ether extract (EE), and ash content [10]. Neutral detergent fiber (NDF) and acid detergent fiber (ADF) were analyzed using an Ankom Fiber Analyzer (Ankom Technologies, Macedon, NY) following the protocol of Van Soest et al. [11].

On day 21 of every period, a sample of $10 \mathrm{~mL}$ of jugular blood was taken at $0 \mathrm{~h}$ before and $4 \mathrm{~h}$ after feeding, and it was kept in a test tube containing $12 \mathrm{mg}$ of ethylenediaminetetraacetic acid. The samples were analyzed for blood urea nitrogen (BUN) using a diagnostic kit (L type, FUJIFILM Wako Chemicals USA Corporation, VA, USA) on the day of sampling. Directly after blood sampling, $200 \mathrm{~mL}$ of ruminal fluid were pumped through a stomach tube at $0 \mathrm{~h}$ before and $4 \mathrm{~h}$ after feeding. The $\mathrm{pH}$ and temperature of ruminal fluid were instantly measured using a HANNA $\mathrm{pH}$ meter (HI 8424, Hanna Instruments, Inc., RI, USA). The ruminal fluid was filtered through a cheesecloth and separated into two parts. First, $45 \mathrm{~mL}$ of filtered ruminal fluid plus $5 \mathrm{~mL}$ of $1 \mathrm{M} \mathrm{H}_{2} \mathrm{SO}_{4}$ were mixed and separated using centrifugation at a speed of $16,000 \mathrm{~g}$ for $15 \mathrm{~min}$. The clear supernatant was used for the analysis of ammonia-nitrogen $\left(\mathrm{NH}_{3}-\mathrm{N}\right)$ using a Kjeltec Auto 1030 analyzer (Foss Inc., Hilleroed, Denmark). The concentration of VFA and VFA profiles was determined using high-pressure liquid chromatography (Instruments by controller water model 600E, water model 484 UV detector, column Nova-Pak C18, column size $4 \times 150 \mathrm{~mm}$, mobile 
phase $10 \mathrm{mM} \mathrm{H}_{2} \mathrm{PO}_{4}$ ( $\mathrm{pH}$ 2.5); ETL Testing Laboratory, Inc., Cortland, NY, USA). Determination of ruminal $\mathrm{CH}_{4}$ concentration using VFA profiles was conducted following Moss et al. [12]: $\mathrm{CH}_{4}$ production $=0.45$ (acetate) -0.275 (propionate) +0.40 (butyrate). The second portion of ruminal fluid was performed to enumerate the protozoal count as well as the fungal zoospore count following Galyean [13].

\section{Statistical analysis}

A $2 \times 2$ factorial arrangement in a $4 \times 4$ Latin square design using the PROC GLM of SAS (SAS Institute Inc., North Carolina, USA) [14] was used to analyze all observed values. Data were analyzed, according to the experimental design, using the model $Y_{i j k}=\mu+M_{i}+E_{j}+A_{k}+P_{l}+\varepsilon_{i j k}$, where $Y_{i j k}$ is the observation for cattle $j$ receiving diet $i$ in period $k, \mu$ is the overall mean, $M_{i}$ is the effect of the levels of crude glycerin $(i=10.5$ and $21 \%), E_{j}$ is the effect of the supplementation levels of chitosan $(j=1 \%$ and $2 \%), A_{k}$ is the influence of the cattle $(k=1,2,3,4), \mathrm{Pl}$ is the influence of the period $(l=1,2,3,4)$, and $\varepsilon_{i j k}$ is the residual effect. Results were demonstrated as mean values with the standard error of the means. Differences between dietary treatment means were determined using Duncan's New Multiple Range Test [15]. $\mathrm{p}<0.05$ was considered statistically significant.

\section{Results}

\section{Nutrient composition}

Tables- 1 and 2 show the nutrient composition of chitosan and TMR containing crude glycerin. The nutrient compositions of the TMR incorporating crude glycerin at $10.5 \%$ and $21 \%$ were similar for DM (92.55\% and $92.84 \%$, respectively), CP (14.06\% and $14.05 \%$, respectively), and ADF (18.45\% and $18.23 \%$, respectively). Fecal samples from cows fed diets with crude glycerin incorporated at $21 \%$ had a low NDF content and high EE compared with crude glycerin incorporated at $10.5 \%$. The crude glycerin was found to contain $62.12 \%$ of glycerin, $48.12 \%$ of EE, $0.50 \%$ of sodium, $5.17 \%$ of methanol, and a smaller amount of other compounds (Table-1). The degree of deacetylation and the chitosan solubility were $88 \%$ and $98.7 \%$, respectively.

\section{Utilization of feed}

Table- 3 shows the DM intake and digestibility of nutrients in response to crude glycerin replacement with the chitosan supplement in the TMR. Interaction effects between the levels of crude glycerin and chitosan were not observed for DM intake and nutrient digestibility, indicating the independent effects of crude glycerin and chitosan. Doses of $21 \%$ crude glycerin decreased DM intake by $0.62 \mathrm{~kg} /$ day compared with lower doses of $10.5 \%$ crude glycerin, whereas nutrient digestibility did not change (Table-3).

\section{pH, ammonia-nitrogen, BUN, protozoa, and fungi}

Table-4 shows the response of $\mathrm{pH}, \mathrm{NH}_{3}-\mathrm{N}, \mathrm{BUN}$, protozoa, and fungi to combined chitosan and crude
Table-1: Chemical composition of crude glycerin.

\begin{tabular}{|c|c|c|}
\hline Items & Content & Analytical method \\
\hline Moisture, \% & 13.65 & AOAC method 984.20 \\
\hline Ash, \% & 8.41 & AOAC method 942.05 \\
\hline Crude protein, \% & 0.02 & AOAC method 990.03 \\
\hline Ether extract, \% & 48.12 & AOAC method $920.39(\mathrm{~A})$ \\
\hline $\begin{array}{l}\text { Gross energy, } \\
\mathrm{kcal} / \mathrm{kg}\end{array}$ & 6380.83 & Adiabatic bomb calorimeter \\
\hline Sodium, \% & 0.50 & $\begin{array}{l}\text { AOAC methods 956.01, } \\
9.15 .01\end{array}$ \\
\hline Calcium, \% & 0.0036 & $\begin{array}{l}\text { AOAC method 2.019, } \\
9.15 .01\end{array}$ \\
\hline Phosphorus, \% & 0.0041 & $\begin{array}{l}\text { AOAC method 2.019, } \\
2.095-7.098\end{array}$ \\
\hline Methanol, \% & 5.17 & $\begin{array}{l}\text { GC/MS with head space } \\
\text { technique, } 973.23[10]\end{array}$ \\
\hline Free fatty acid, \% & 0.52 & $\begin{array}{l}\text { GC/MS with head space } \\
\text { technique, } 973.23[10]\end{array}$ \\
\hline $\mathrm{pH}$ & 9.85 & $\begin{array}{l}\text { Orion } 230 \mathrm{~A} \text { pH meter with } \\
9107 \mathrm{BN} \text { probe (ISO } 12185 \text { ) }\end{array}$ \\
\hline
\end{tabular}

Table-2: Ingredients and chemical composition used in the total mixed ration.

\begin{tabular}{lccc}
\hline Items & \multicolumn{2}{c}{$\begin{array}{c}\text { Incorporated } \\
\text { crude glycerin } \\
\text { levels, \% }\end{array}$} & \\
\cline { 2 - 3 } & $\mathbf{1 0 . 5}$ & $\mathbf{2 1}$ & \\
\hline Ingredients, kg DM & & & \\
Rice straw & 30.00 & 30.00 & \\
Crude glycerin & 10.50 & 21.00 & \\
Cassava chips & 30.00 & 20.00 & \\
Rice bran & 6.90 & 6.31 & \\
Palm kernel meal & 9.00 & 9.00 & \\
Soybean meal & 9.00 & 9.00 & \\
Molasses, liquid & 1.00 & 1.00 & \\
Urea & 2.10 & 2.19 & \\
Pure sulfur & 0.50 & 0.50 & \\
Mineral premix & 0.50 & 0.50 & \\
Salt & 0.50 & 0.50 & \\
Chemical composition & & & \\
DM, \% & 92.55 & 92.84 & 98.90 \\
Organic matter, \%DM & 95.12 & 94.20 & 99.73 \\
Ash, \%DM & 4.88 & 5.80 & 0.27 \\
Crude protein, \%DM & 14.06 & 14.05 & 0.53 \\
Ether extract, \%DM & 4.82 & 8.19 & - \\
Neutral detergent fiber, \%DM & 44.53 & 40.98 & - \\
Acid detergent fiber, \%DM & 18.45 & 18.23 & - \\
Solubility, \% & - & - & 98.70 \\
Deacetylation degree, \% & - & - & 88.00 \\
\hline DM=Dry matter & \multicolumn{3}{c}{} \\
\hline
\end{tabular}

DM=Dry matter

glycerin supplementation. The incorporated crude glycerin and supplemented chitosan levels did not affect the $\mathrm{pH}$ or temperature. However, the concentrations of $\mathrm{NH}_{3}-\mathrm{N}$ were significantly different when comparing incorporated and supplemented levels at $4 \mathrm{~h}$ after feeding, with the average being $13.74-14.33 \mathrm{mg} / \mathrm{dl}$, respectively. The effects of combined crude glycerin and chitosan supplementation on rumen protozoal populations and total fungi counts are shown in Table- 4 . The protozoal populations and total fungi counts were unchanged.

\section{Methane estimation, molar portions, and total VFAs}

Table-5 presents the total VFAs, molar portions of VFAs, and estimated $\mathrm{CH}_{4}$ of ruminal fluid from cattle 
Available at www.veterinaryworld.org/Vol.14/May-2021/14.pdf

Table-3: Effect of crude glycerin with chitosan on feed intake and apparent digestibility in Thai native bulls.

\begin{tabular}{|c|c|c|c|c|c|c|c|c|}
\hline \multirow[t]{2}{*}{ Items } & \multicolumn{2}{|c|}{$10.5 \%$ CG } & \multicolumn{2}{|c|}{$21 \%$ CG } & \multirow[t]{2}{*}{ SEM } & \multirow[t]{2}{*}{ CG } & \multirow[t]{2}{*}{ CH } & \multirow[t]{2}{*}{ Interaction } \\
\hline & $1 \% \mathrm{CH}$ & $2 \% \mathrm{CH}$ & $1 \% \mathrm{CH}$ & $2 \% \mathrm{CH}$ & & & & \\
\hline \multicolumn{9}{|l|}{ DM intake } \\
\hline kg/day & 4.76 & 4.84 & 4.48 & 3.88 & 0.30 & 0.06 & 0.28 & 0.39 \\
\hline$\%$ BW & 3.59 & 2.91 & 2.41 & 2.36 & 0.20 & $<0.01$ & 0.26 & 0.06 \\
\hline $\mathrm{g} / \mathrm{kg}$ of $\mathrm{BW}^{0.75}$ & 115.96 & 102.55 & 90.75 & 96.32 & 7.02 & 0.04 & 0.62 & 0.18 \\
\hline \multicolumn{9}{|c|}{ Digestibility coefficients, \%DM } \\
\hline DM & 62.98 & 64.80 & 64.47 & 61.41 & 2.00 & 0.64 & 0.76 & 0.10 \\
\hline Organic matter & 66.39 & 66.26 & 66.26 & 64.94 & 0.81 & 0.38 & 0.38 & 0.60 \\
\hline Crude protein & 60.67 & 66.67 & 66.29 & 64.39 & 2.23 & 0.46 & 0.37 & 0.53 \\
\hline Neutral detergent fiber & 54.81 & 56.74 & 53.45 & 53.79 & 1.30 & 0.06 & 0.63 & 0.76 \\
\hline Acid detergent fiber & 46.04 & 44.47 & 45.62 & 46.89 & 1.11 & 0.38 & 0.89 & 0.68 \\
\hline
\end{tabular}

$\mathrm{CG}=$ Crude glycerin, $\mathrm{CH}=$ Chitosan, $\mathrm{SEM}=$ Standard error of mean, $\mathrm{DM}=$ Dry matter

Table-4: Effect of crude glycerin with chitosan on ruminal $\mathrm{pH}$, rumen temperature, concentrations of rumen ammonianitrogen $\left(\mathrm{NH}_{3}-\mathrm{N}\right)$, and blood metabolites

\begin{tabular}{|c|c|c|c|c|c|c|c|c|}
\hline \multirow[t]{2}{*}{ Items } & \multicolumn{2}{|c|}{$10.5 \%$ CG } & \multicolumn{2}{|c|}{$21 \%$ CG } & \multirow[t]{2}{*}{ SEM } & \multirow[t]{2}{*}{ CG } & \multirow[t]{2}{*}{$\mathbf{C H}$} & \multirow[t]{2}{*}{ Interaction } \\
\hline & $1 \% \mathrm{CH}$ & $2 \% \mathrm{CH}$ & $1 \% \mathrm{CH}$ & $2 \% \mathrm{CH}$ & & & & \\
\hline \multicolumn{9}{|l|}{ Ruminal $\mathrm{pH}$} \\
\hline $0 \mathrm{~h}$ post-feeding & 6.77 & 6.76 & 6.80 & 6.79 & 0.03 & 0.37 & 0.76 & 0.94 \\
\hline $4 \mathrm{~h}$ post-feeding & 6.68 & 6.67 & 6.71 & 6.75 & 0.03 & 0.34 & 0.81 & 0.97 \\
\hline Mean & 6.72 & 6.72 & 6.76 & 6.75 & 0.03 & 0.50 & 0.96 & 0.66 \\
\hline \multicolumn{9}{|l|}{ Temperature, ${ }^{\circ} \mathrm{C}$} \\
\hline $0 \mathrm{~h}$ post-feeding & 39.01 & 38.95 & 38.76 & 39.37 & 0.25 & 0.97 & 0.45 & 0.32 \\
\hline $4 \mathrm{~h}$ post-feeding & 39.03 & 40.02 & 39.53 & 39.61 & 0.29 & 0.98 & 0.10 & 0.41 \\
\hline Mean & 39.16 & 39.49 & 39.15 & 39.49 & 0.23 & 0.98 & 0.18 & 0.98 \\
\hline \multicolumn{9}{|c|}{$\mathrm{NH}_{3}-\mathrm{N}$ concentration, $\mathrm{mg} / \mathrm{dl}$} \\
\hline $0 \mathrm{~h}$ post-feeding & 12.55 & 13.13 & 12.29 & 12.24 & 0.51 & 0.29 & 0.63 & 0.56 \\
\hline $4 \mathrm{~h}$ post-feeding & 13.86 & 14.26 & 14.33 & 13.74 & 0.57 & 0.94 & 0.88 & 0.39 \\
\hline Mean & 13.20 & 13.69 & 13.31 & 12.99 & 0.50 & 0.56 & 0.87 & 0.43 \\
\hline \multicolumn{9}{|c|}{ Blood urea nitrogen concentration, mg/dl } \\
\hline $0 \mathrm{~h}$ post-feeding & 14.25 & 13.75 & 13.75 & 15.50 & 1.33 & 0.64 & 0.64 & 0.41 \\
\hline $4 \mathrm{~h}$ post-feeding & 15.50 & 15.25 & 15.50 & 15.75 & 0.60 & 0.68 & 1.00 & 0.68 \\
\hline Mean & 14.87 & 14.50 & 14.62 & 15.62 & 0.76 & 0.57 & 0.69 & 0.38 \\
\hline \multicolumn{9}{|c|}{ Protozoa $\times 10^{6} \mathrm{cell} / \mathrm{mL}$} \\
\hline $0 \mathrm{~h}$ post-feeding & 1.75 & 1.75 & 1.88 & 1.87 & 0.39 & 0.74 & 0.98 & 0.99 \\
\hline $4 \mathrm{~h}$ post-feeding & 1.62 & 2.12 & 1.75 & 1.50 & 0.34 & 0.47 & 0.72 & 0.29 \\
\hline Mean & 1.88 & 1.93 & 1.82 & 1.68 & 0.25 & 0.82 & 0.82 & 0.47 \\
\hline \multicolumn{9}{|l|}{ Fungal $\times 10^{4}$ cell $/ \mathrm{mL}$} \\
\hline $0 \mathrm{~h}$ post-feeding & 1.00 & 1.12 & 1.25 & 1.00 & 0.17 & 0.72 & 0.72 & 0.29 \\
\hline $4 \mathrm{~h}$ post-feeding & 1.00 & 1.62 & 2.12 & 1.37 & 0.49 & 0.39 & 0.90 & 0.18 \\
\hline Mean & 1.00 & 1.37 & 1.68 & 1.18 & 0.28 & 0.38 & 0.82 & 0.13 \\
\hline
\end{tabular}

$\mathrm{CG}=$ Crude glycerin, $\mathrm{CH}=$ Chitosan, $\mathrm{SEM}=$ Standard error of mean

fed different concentrations of supplemented chitosan and crude glycerin. Supplemented chitosan and incorporated crude glycerin in the cattle diets did not affect the molar portions and total VFAs, but they did affect the estimated $\mathrm{CH}_{4}$. Increasing the incorporated crude glycerin levels increased propionate and decreased the ratio of acetate to propionate ratio, whereas the butyrate, acetate, and total VFAs were unchanged. The TMR containing $21 \%$ crude glycerin with chitosan supplementation at $2 \%$ reduced $\mathrm{CH}_{4}$ estimation by $5.08 \%$ compared with the treatment of $10.5 \%$ crude glycerin and $1 \%$ chitosan supplementation.

\section{Discussion}

The low NDF and high EE of the TMR, when $21 \%$ of crude glycerin was incorporated, could be due to the high content of EE (48.75\%) and the low NDF content in the crude glycerin. The methanol content in the crude glycerin was $5.17 \%$ (Table-2), which was considered to be safe for animals, and this was in agreement with Lage et al. [16] who demonstrated that feeding feedlot lambs crude glycerin containing $8.7 \%$ methanol at $12 \%$ on the DM basis of a concentrate diet did not negatively affect their health. The ash content in chitosan was lower than the critical value of $1 \%$ based on the method used by Toan [9].

In this experiment, a decrease in DM intake was found when beef cattle were fed up to $21 \%$ crude glycerin. Similarly, Paiva et al. [17] noted a reduction of $4.1 \%$ in DM intake of cows fed $21 \%$ crude glycerin compared with cows fed a control diet. This finding was likely because crude glycerin has a high EE content (48.75\%) and can affect oxidation reactions and enhance Krebs cycle substrate synthesis 
Table-5: Effect of crude glycerin with chitosan on total volatile fatty acids and molar portions of volatile fatty acids of Thai native bulls.

\begin{tabular}{|c|c|c|c|c|c|c|c|c|}
\hline \multirow[t]{2}{*}{ Items } & \multicolumn{2}{|c|}{$10.5 \%$ CG } & \multicolumn{2}{|c|}{$21 \%$ CG } & \multirow[t]{2}{*}{ SEM } & \multirow[t]{2}{*}{ CG } & \multirow[t]{2}{*}{$\mathbf{C H}$} & \multirow[t]{2}{*}{ Interaction } \\
\hline & $1 \% \mathrm{CH}$ & $2 \% \mathrm{CH}$ & $1 \% \mathrm{CH}$ & $2 \% \mathrm{CH}$ & & & & \\
\hline \multicolumn{9}{|c|}{ Total volatile fatty acids, $\mathrm{mmol} / \mathrm{L}$} \\
\hline $0 \mathrm{~h}$ post-feeding & 101.56 & 105.62 & 102.08 & 100.45 & 2.16 & 0.47 & 0.70 & 0.38 \\
\hline $4 \mathrm{~h}$ post-feeding & 114.69 & 118.12 & 116.51 & 117.37 & 5.79 & 0.85 & 0.45 & 0.65 \\
\hline Mean & 108.13 & 111.87 & 109.30 & 108.91 & 3.31 & 0.70 & 0.47 & 0.38 \\
\hline \multicolumn{9}{|l|}{ Acetic acid, \% } \\
\hline $0 \mathrm{~h}$ post-feeding & 61.80 & 63.08 & 60.52 & 60.70 & 1.92 & 0.36 & 0.69 & 0.79 \\
\hline $4 \mathrm{~h}$ post-feeding & 66.57 & 62.35 & 66.60 & 60.95 & 2.51 & 0.79 & 0.07 & 0.78 \\
\hline Mean & 64.19 & 62.71 & 63.56 & 60.88 & 1.85 & 0.51 & 0.28 & 0.75 \\
\hline \multicolumn{9}{|l|}{ Propionic acid, \% } \\
\hline $0 \mathrm{~h}$ post-feeding & 20.05 & 21.17 & 21.77 & 22.67 & 1.54 & 0.31 & 0.52 & 0.94 \\
\hline $4 \mathrm{~h}$ post-feeding & 21.07 & 22.71 & 25.51 & 27.13 & 1.53 & 0.01 & 0.30 & 0.99 \\
\hline Mean & 20.56 & 21.94 & 23.64 & 24.90 & 1.39 & 0.05 & 0.36 & 0.96 \\
\hline \multicolumn{9}{|l|}{ Butyric acid, \% } \\
\hline $0 \mathrm{~h}$ post-feeding & 11.39 & 14.00 & 12.70 & 13.28 & 1.67 & 0.86 & 0.35 & 0.55 \\
\hline $4 \mathrm{~h}$ post-feeding & 14.10 & 15.60 & 15.88 & 15.90 & 2.43 & 0.67 & 0.76 & 0.76 \\
\hline Mean & 12.75 & 14.80 & 14.29 & 14.59 & 1.94 & 0.73 & 0.55 & 0.65 \\
\hline \multicolumn{9}{|c|}{ Acetic/propionic acid ratio } \\
\hline $0 \mathrm{~h}$ post-feeding & 2.11 & 2.64 & 2.25 & 2.41 & 0.20 & 0.83 & 0.11 & 0.37 \\
\hline $4 \mathrm{~h}$ post-feeding & 3.56 & 3.52 & 2.71 & 2.48 & 0.27 & $<0.01$ & 0.62 & 0.72 \\
\hline Mean & 2.29 & 2.68 & 2.88 & 2.98 & 0.22 & 0.06 & 0.28 & 0.52 \\
\hline \multicolumn{9}{|c|}{ Acetic plus butyric acid-to-propionic acid ratio } \\
\hline $0 \mathrm{~h}$ post-feeding & 2.57 & 3.32 & 3.23 & 2.68 & 0.19 & 0.95 & 0.60 & 0.54 \\
\hline $4 \mathrm{~h}$ post-feeding & 3.62 & 3.90 & 3.67 & 3.21 & 0.42 & 0.46 & 0.83 & 0.39 \\
\hline Mean & 3.10 & 3.61 & 3.45 & 2.95 & 0.27 & 0.57 & 0.98 & 0.08 \\
\hline \multicolumn{9}{|c|}{ Methane $\left(\mathrm{CH}_{4}\right)$ estimation, $\mathrm{mM} / \mathrm{L}$} \\
\hline $0 \mathrm{~h}$ post-feeding & 27.84 & 27.67 & 27.05 & 26.88 & 0.44 & 0.99 & 0.70 & 0.99 \\
\hline $4 \mathrm{~h}$ post-feeding & 33.87 & 33.20 & 33.08 & 29.23 & 1.86 & 0.24 & 0.40 & 0.23 \\
\hline Mean & 29.35 & 29.13 & 28.14 & 27.86 & 0.47 & 0.94 & 0.60 & 0.02 \\
\hline
\end{tabular}

$\mathrm{CG}=$ Crude glycerin, $\mathrm{CH}=$ Chitosan, $\mathrm{SEM}=$ Standard error of mean

in the liver, activating satiety, and decreasing DM intake. In addition, crude glycerin containing methanol at $5.17 \%$ adversely affects the acceptability of the diet.

Increasing the level of crude glycerin replacement in the diet with chitosan supplementation did not change nutrient digestibility. Rather, crude glycerin might partially replace carbohydrate sources in TMR diets without negatively affecting nutrient digestibility. Other in vitro studies have also reported no change in nutrient digestion with dietary inclusion of $21 \%$ crude glycerin with $2 \%$ chitosan [18]. These results are similar to previous research in which crude glycerin comprised up to $10 \%$ of the diet, resulting in no change in nutrient digestibility [19]. In contrast, Paiva et al. [17] indicated that the inclusion of crude glycerin could reduce fiber digestion due to glycerin inhibiting the activity and growth of fibrolytic microorganisms. Therefore, the differing effect of glycerin on feed digestion might be influenced by the dose and quality of crude glycerin as well as the feeding pattern [20].

The previous research showed that ruminal $\mathrm{pH}$ and temperature were not changed by doses of crude glycerin with chitosan supplementation and were noted as being suitable for bacterial activity [18]. Various doses of crude glycerin with chitosan did not affect the rumen $\mathrm{NH}_{3}-\mathrm{N}$ and BUN concentration, which could be because the TMR diets contained similar CP (14\% DM) and the crude glycerin with chitosan did not provide a source of nitrogen.

In the present study, supplementing beef cattle with crude glycerin $(21 \%$ vs. $10.5 \%$ crude glycerin in the TMR diets) enhanced the propionate concentration in the rumen $(20.24 \%)$ and decreased the acetate to propionate ratio (12\%). Similarly, Chanjula et al. [5] reported that replacing ground corn with crude glycerin at $20 \%$ linearly increased propionate by $47 \%$ when compared with the group fed no crude glycerin. It is likely that crude glycerin underwent rumen fermentation and concerted to propionate, which is similar to a fermentable energy source $[5,17]$. Furthermore, change in the propionate concentration could be because of the utilization of crude glycerin by Selenomonas spp. in the rumen [2].

The combination of supplemented crude glycerin and chitosan could depress $\mathrm{CH}_{4}$ estimation more effectively than when either of these components is added alone. The TMR containing $21 \%$ crude glycerin with supplemented chitosan at $2 \%$ reduced $\mathrm{CH}_{4}$ estimation more than that of other groups. It is possible that the high level of crude glycerin could change the cell membrane permeability of methanogenic bacteria, limiting $\mathrm{CH}_{4}$ synthesis [21]. In addition, glycerin is rapidly changed to propionate in the rumen, and propionate acts as a hydrogen sink in the rumen. 
Therefore, enhancing its proportion might decrease hydrogen availability and reduce $\mathrm{CH}_{4}$ production. Our results agree with a study by Chanjula et al. [5] who found a linear reduction in the concentration of $\mathrm{CH}_{4}$ when increasing the level of crude glycerin up to $20 \%$. Furthermore, the lower $\mathrm{CH}_{4}$ production when supplementing with a high dose of chitosan could be due to positively charged chitosan interrupting negatively charged methanogen bacteria and leading to damaged protein and other cell components of the cytosol [8]. Similarly, Haryati et al. [7] indicated that $\mathrm{CH}_{4}$ synthesis was reduced when $2 \%$ chitosan was supplemented. In earlier work, our in vitro experiment demonstrated that a combination of $21 \%$ crude glycerin and $2 \%$ chitosan supplementation in the TMR reduced $\mathrm{CH}_{4}$ synthesis by $53.67 \%$ when compared to the non-supplemented treatment [18].

\section{Conclusion}

Incorporating high concentrations of crude glycerin in the TMR resulted in reducing feed intake, but it had no negative effect on feed digestion and rumen ecology. Increasing the incorporated crude glycerin levels in the TMR significantly elevated the propionate concentration. The TMR cattle diet containing the combination of $21 \%$ crude glycerin and $2 \%$ chitosan reduced $\mathrm{CH}_{4}$ estimation more effectively than individual addition of these supplements. Future animal production trials should investigate the combined effect of crude glycerin with chitosan.

\section{Authors' Contributions}

$\mathrm{AS}$ and AC: Conceptualization. AS and AC: Formal analysis. MW and AC: Funding acquisition. $\mathrm{AS}, \mathrm{SS}$, and $\mathrm{AC}$ : Investigation. $\mathrm{AS}$ and $\mathrm{AC}$ : Methodology. MW and AC: Supervision. All authors read and approved the final manuscript.

\section{Acknowledgments}

This research was funded by the Research Program on Increasing the Potential Production of Thai Native Beef Cattle with Innovation and Biotechnology in Animal Feed, the Increase Production Efficiency and Meat Quality of Native Beef and Buffalo Research Group, the Research Program on Toxic Substances, Microorganisms and Feed Additives in Livestock and Aquatic Animals for Food Safety, Khon Kaen University (KKU), and the International Research Network (IRN) (IRN57W0002, Contract No. IRG5980010). We thank the Tropical Feed Resources Research and Development Center, and Department of Animal Science, Faculty of Agriculture, KKU, for the use of the research facilities as well as the Biodiesel Production from Used Oil Project, KKU, Thailand, in supporting crude glycerin.

\section{Competing Interests}

The authors declare that they have no competing interests.

\section{Publisher's Note}

Veterinary World remains neutral with regard to jurisdictional claims in published institutional affiliation.

\section{References}

1. Almeida, M.T.C., Ezequiel, J.M.B., Paschoaloto, J.R., Perez, H.L., Carvalho, V.B. and Filho, E.S.C. (2018) Rumen and liver measurements of lambs fed with high inclusions of crude glycerin in adaptation and finishing period of feedlot. Small Rumin. Res., 167(11): 1-5.

2. van Cleef, E.H.C., Almeida, M.T.C., Perez, H.L., Paschoaloto, J.R., Filho, E.S.C. and Ezequiel. J.M.B. (2018) Effects of partial or total replacement of corn cracked grain with high concentrations of crude glycerin on rumen metabolism of crossbred sheep. Small Rumin. Res., 159(2): 45-51.

3. Karlsson, J., Ramin, M., Kass, M., Lindberg, M. and Holtenius, K. (2019) Effects of replacing wheat starch with glycerol on methane emissions, milk production, and feed efficiency in dairy cows fed grass silage-based diets. $J$. Dairy Sci., 102(9): 7927-7935.

4. Avila, S.J., Chaves, A.V., He, M.L., Harstad, O.M., Beauchemin, K.A., McGinn, S.M. and McAllister, T.A. (2013) Effects of increasing concentrations of glycerol in concentrate diets on nutrient digestibility, methane emissions, growth, fatty acid profiles, and carcass traits of lambs. J. Anim. Sci., 91(2): 829-837.

5. Chanjula, P., Pakdeechanuan, P. and Wattanasit, S. (2014) Effects of dietary crude glycerin supplementation on nutrient digestibility, ruminal fermentation, blood metabolites, and nitrogen balance of goats. Asian-Australas. J. Anim. Sci., 27(3): 365-374.

6. Pereira, F.M., Carvalho, G.G.P., Magalhães, T.S., Freitas, J.J.E., Azevêdo, J.A.G., Mourão, G.B., Pires, A.J.V., Eiras, C.E., Novais-Eiras, D. and Filho, A.E. (2018) Effect of chitosan on production performance of feedlot lambs. $J$. Agric. Sci., 156(9): 1138-1144.

7. Haryati, R.P., Jayanegara, A., Laconi, E.B., Ridla, M. and Suptijah, P. (2019) Evaluation of chitin and chitosan from insect as feed additives to mitigate ruminal methane emission. AIP Conf. Proc., 2120(1): 040008.

8. Zanferari, F., Vendramini, T.H.A., Rentas, M.F., Gardinal, R., Calomeni, G.D., Mesquita, L.G., Takiya, C.S. and Rennó, F.P. (2018) Effects of chitosan and whole raw soybeans on ruminal fermentation and bacterial populations, and milk fatty acid profile in dairy cows. J. Dairy Sci., 101(12): 10939-10952.

9. Toan, N.V. (2009) Production of chitin and chitosan from partially autolyzed shrimp shell materials. Open Biom. J., 1(1): 21-24.

10. AOAC. (1995) Official Methods of Analysis: Animal Feeds. $16^{\text {th }}$ ed. Association of Official Analytical Chemists, Virginia, USA.

11. van Soest, P.J., Robertson, J.B. and Lewis, B.A. (1991) Methods for dietary fiber neutral detergent fiber, and nonstarch polysaccharides in relation to animal nutrition. $J$. Dairy Sci., 74(10): 3583-3597.

12. Moss, A.R., Jouany, J.P. and Newbold, J. (2000) Methane production by ruminants: Its contribution to global warming. Ann. Zootech., 49(3): 231-253.

13. Galyean, M. (1989) Laboratory Procedure in Animal Nutrition Research. Department of Animal and Range Sciences. New Mexico State University, Las Cruces, NM, USA.

14. Statistical Analysis Systems. (1996) SAS/STAT User's Guide: Version 6.12. $4^{\text {th }}$ ed. SAS Inc., Cary, NC

15. Steel, R.G.D. and Torrie, J.H. (1980) Principles and Procedures of Statistics. McGraw Hill Book Co., New York.

16. Lage, J.F., Paulino, P.V., Pereira, L.G., Duarte, M.S., Filho, S.C.V., Oliveira, A.S., Souza, N.K.P. and Lima, J.C.M. 
(2014) Carcass characteristics of feedlot lambs fed crude glycerin contaminated with high concentrations of crude fat. Meat Sci., 96(1): 108-113.

17. Paiva, P.G., del Valle, T.A., Jesus, E.F., Bettero, V.P., Almeida, G.F., Bueno, I.C.S., Bradford, B.J. and Rennó, F.P. (2016) Effects of crude glycerin on milk composition, nutrient digestibility and ruminal fermentation of dairy cows fed corn silage-based diets. Anim. Feed Sci. Technol., 212(2): 136-142.

18. Seankamsorn, A., Cherdthong, A. and Wanapat, M. (2020) Combining crude glycerin with chitosan can manipulate in vitro ruminal efficiency and inhibit methane synthesis.
Animals, 10(1): 37.

19. Trabue, S., Scoggin, K., Tjandrakusuma, S., Rasmussen, M.A. and Reilly, P.J. (2007) Ruminal fermentation of propylene glycol and glycerol. J. Agric. Food Chem., 55(17): 7043-7051.

20. Kholif, A.E. (2019) Glycerol use in dairy diets: A systemic review. Anim. Nutr., 5(3): 209-216.

21. Belanche, A., Pinloche, E., Preskett, D. and Newnold, C.J. (2019) Effects and mode of action of chitosan and ivy fruit saponins on the microbiome, fermentation and methanogenesis in the rumen simulation technique. FEMS Microbiol. Ecol., 92(1): 1-13.

$* * * * * * * *$ 